\title{
The Clinical Effectiveness of Bariatric Surgery with Morbid Obesity
}

\author{
Mehmet Serdar Cengizhan ${ }^{1}$ and Mehmet Çelik ${ }^{2 *}$ \\ ${ }^{1}$ Bilecik State Hospital, Department of Internal Medicine, Turkey \\ ${ }^{2}$ Bilecik State Hospital, Department of Endocrinology and Metabolism, Turkey
}

Submission: March 28, 2018; Published: April 19, 2018

*Corresponding author: Mehmet Çelik, Bilecik State Hospital, Department of Endocrinology and Metabolism, Turkey,

Email:drmehmetcelik@hotmail.com

\section{Abstract}

Obesity is a preventable condition that causes morbidity most often after cessation. In the treatment of obesity, life style changes as well as medical treatment. However, in cases where these conditions are insufficient, surgery can be used to prevent morbid obesity has become the main part. For this purpose, Roux-en-Y gastric bypass, sleeve gastrectomy, adjustable gastric band and biliopancreatic diversion are the most commonly used surgical procedures.

Keywords: Obesity; Surgical treatment

\section{Introduction}

Currently the prevalence of Obesity is nearly 35\% (BMI>30) and $70 \%$ (BMI>25) and the prevalence of Diabetes Mellitus is $>7 \%$.One of the first drugs used in the treatment of obesity was Orlistat. A reduction of approximately $3 \mathrm{~kg}$ was observed following 2 years of use of Orlistat treatment. Regular exercise in addition to diet and Orlistat treatment is also known to be beneficial for weight loss. It has been shown in obese patients that dieting and exercise reduce $10 \mathrm{~kg}$ of systolic blood pressure by approximately $6 \mathrm{mmHg}$ and diastolic blood pressure by $3.5 \mathrm{mmHg}[1]$.

Similarly, a $10 \%$ weight loss in obese patients has been shown to improve Cardiovascular Disease, Diabetes, Hypertension, Hyperlipidemia, Osteoarthritis and Sleep Apnea by about $5-10 \%$ [1-7]. The first bariatric surgery was performed with jejunoileal by-pass in 1954, but unfortunately diarrhea and nutritional deficiencies after this procedure were frequent and the application of this procedure with the complication of irreversible hepatic cirrhosis was left to be applied. The first Gastric By-pass was made by Mason and Ito [8]. A second widely used technique outside of U.S.A is the laparoscopic adjustable gastric band process. These last 2 procedures are to ensure that priority is given to weight loss from malabsorption. Worldwide data in 2002 and 2003 showed that gastric bypass surgery was performed with the majority (65.1\%) for weight loss [1].
Randomized-control trials (RCT) were conducted to observe the weight loss effect of bariatric surgery, which had been well experienced for many years. In those RCT, the patients were divided into two groups, the first group was gastroplasty and diet treatment, the second group was only diet therapy.In this study, patients' weight loss ratios were compared at $6^{\text {th }}$ and $24^{\text {th }}$ months. There was no significant difference between the two groups at the end of 6 months. There was a significant difference in the basal weights according to the group that did not receive any surgical treatment at the $24^{\text {th }}$ month $(30.5 \mathrm{~kg}$ vs. $8.0 \mathrm{~kg}$ for surgical and nonsurgical therapy, respectively) $[9,10]$.

Another important study is on obese adults in the Swedish Obese Subjects (S.O.S.). In adults included in this study, the body mass index (BMI) in men was $\geq 34 \mathrm{~kg} / \mathrm{m}^{2}$ and the in women BMI was $\geq 38 \mathrm{~kg} / \mathrm{m}^{2}$. The mean BMI of the patients included in this study was $41 \mathrm{~kg} / \mathrm{m}^{2}$ and approximately two-thirds of the patients were female. In the SOS study, the average weight loss was found to be $20 \mathrm{~kg}$ in the patient group who underwent surgical treatment for 8 years, but the mean weight was not changed only in the patients who were followed only medically. In this SOS study, the patients treated with RYGB (Rouxen-Y gastric bypass), more weight loss was observed in patients treated with vertical banded gastroplasty or only patients who underwent band procedure [11-15]. 


\section{Current Research in Diabetes \& Obesity Journal}

Surgical treatment has been shown to be superior to obesity and obesity-related diseases in terms of surgical treatment compared to surgical treatment with medical treatment in SOS study. It has been shown that Diabetes, Hypertension and Lipid abnormalities significantly decreased in 845 patients who underwent surgical treatment and 845 patients in control compared with 24 months follow-up after surgical treatment [13]. Although the risk of decreased hypertension persisted at the $8^{\text {th }}$ year after surgery, the effect of reducing the risk of developing diabetes was still dramatic [12]. In addition, S.O.S studies have shown that sleep apnea reduction benefits in patients with sleep apnea are also beneficial and have therapeutic effects on dyspnea and chest pain [14].

\section{Discussion}

Bariatric surgery appears to be more effective in weight loss than without obesity surgery and only takes in medical care, especially in patients with a BMI of $40 \mathrm{~kg} / \mathrm{m}^{2}$, at least for 10 years, and is more effective in reducing the incidence of obesityrelated diseases.

\section{Indications for bariatric surgery [16]}

\section{1. $\mathrm{BMI} \geq 40 \mathrm{~kg} / \mathrm{m}^{2}$}

2. BMI $>35 \mathrm{~kg} / \mathrm{m}^{2}$ and obesity-related comorbidities (Type 2 Diabetes, OSAS, severe HTetc.) cannot be controlled by medical treatment and lifestyle changes.

3. Non-surgical methods have already been applied but failed.

Today, however, thanks to advancing medicine, new genes, new peptides and hormones that cause Obesity are being discovered. In particular, specialists in internal medicine and endocrinology/ metabolism have the opportunity to diagnose and treat diseases that may cause obesity at an early stage. Examples of such diseases include hypothyroidism, Cushing's disease, and Diabetes mellitus, and these disease cases can be further amplified. Bariatric surgery is an important and effective treatment modality in patients with morbid obesity. However, patients diagnosed with morbid obesity should be screened in detail in terms of hormonal diseases that may lead to obesity before being directed to bariatric surgery. Because many diseases that may cause obesity nowadays have effective medical treatment approaches if appropriate diagnosis is made. Likewise, changing patients' lifestyles, avoiding ready-to-eat food, and healthy eating and exercising regularly will significantly reduce obesity. Similarly, it is equally important to inform and raise awareness of obesity to begin within childhood. There is not yet sufficient and convincing data on long term effects of bariatric surgery.Therefore, it is very important that the patient group planned to be treated with bariatric surgery is thoroughly screened for any other known diseases that may lead to obesity before surgery, and that surgical treatment is guided only after the benefit/ damage rates of selected patients are calculated.
Finally, with a better understanding of the pathophysiology of diseases day by day, it is thought that the diseases that can cause obesity in the coming years and the medical treatments of these diseases are better understood. Therefore, further study and data collection of bariatric surgery and benefits and complications after bariatric surgery, whose long-term harms and benefits still remain unclear, are needed.

\section{References}

1. Avenell A, Broom J, Brown TJ, Poobalan A, Aucott L, et al. (2004) Systematic review of the long-term effects and economic consequences of treatments for obesity and implications for health improvement. Health Technol Assess 8(21): iii-iv, 1-182.

2. Pi Sunyer FX (1996) A review of long-term studies evaluating the efficacy of weight loss in ameliorating disorders associated with obesity. Clin Ther 18(6): 1006-1035.

3. Torgerson JS, Hauptman J, Boldrin MN, Sjostrom L (2004) XENical in the prevention of diabetes in obese subjects (XENDOS) study: a randomized study of orlistat as an adjunct to lifestyle changes for the prevention of type 2 diabetes in obese patients. Diabetes Care 27(1): 155-161.

4. Wing RR, Hamman RF, Bray GA, Delahanty L, Edelstein SL, et al. (2004) Achieving weight and activity goals among diabetes prevention program lifestyle participants. Obes Res 12(9): 1426-1434.

5. Klein S, Sheard NF, Pi Sunyer X, Daly A, Wylie Rosett J, et al. (2004) Weight management through lifestyle modification for the prevention and management of type 2 diabetes: rationale and strategies: a statement of the American Diabetes Association, the North American Association for the Study of Obesity, and the American Society for Clinical Nutrition. Am J Clin Nutr 80(2): 257-263.

6. Stevens VJ, Obarzanek E, Cook NR, Lee IM, Appel LJ, et al. (2001) Longterm weight loss and changes in blood pressure: results of the Trials of Hypertension Prevention, phase II. Ann Intern Med 134(1): 1-11.

7. Dattilo AM, Kris Etherton PM (1992) Effects of weight reduction on blood lipids and lipoproteins: a meta-analysis. Am J Clin Nutr 56(2): 320-328.

8. Mason EE, Ito C (1967) Gastric bypass in obesity. Surg Clin North Am 47(6): 1345-1351.

9. Andersen T, Backer OG, Stokholm KH, Quaade F (1982) Gastroplasty versus very low calorie diet in morbid obesity. Short-term results of a randomized clinical trial. Ugeskr Laeger 144(6): 390-394.

10. Andersen T, Backer OG, Stokholm KH, Quaade F (1984) Randomized trial of diet and gastroplasty compared with diet alone in morbid obesity. N Engl J Med 310(6): 352-356.

11. Sjostrom CD, Peltonen M, Sjostrom L (2001) Blood pressure and pulse pressure during long-term weight loss in the obese: the Swedish Obese Subjects (SOS) Intervention Study. Obes Res 9(3): 188-195.

12. Sjostrom CD, Peltonen M, Wedel H, Sjostrom L (2000) Differentiated long-term effects of intentional weight loss on diabetes and hypertension. Hypertension 36(1): 20-25.

13. Sjostrom CD, Lissner L, Wedel H, Sjostrom L (1999) Reduction in incidence of diabetes, hypertension and lipid disturbances after intentional weight loss induced by bariatric surgery: the SOS Intervention Study. Obes Res 7(5): 477-484.

14. Karason K, Lindroos AK, Stenlof K, Sjostrom L (2000) Relief of cardiorespiratory symptoms and increased physical activity after surgically induced weight loss: results from the Swedish Obese Subjects study. Arch Intern Med 160(12): 1797-1802.

15. Torgerson JS, Sjostrom L (2001) The Swedish Obese Subjects (SOS) study-rationale and results. Int J Obes Relat Metab Disord 25 Suppl 1: S2-S4. 


\section{Current Research in Diabetes \& Obesity Journal}

16. (1991) NIH conference. Gastrointestinal surgery for severe obesity. Consensus Development Conference Panel. Ann Intern Med 115(12): 956-961.

(C) This work is licensed under Creative
Commons Attribution 4.0 Licens
DOI: $10.19080 /$ CRDOJ.2018.07.555701

\section{Your next submission with Juniper Publishers} will reach you the below assets

- Quality Editorial service

- Swift Peer Review

- Reprints availability

- E-prints Service

- Manuscript Podcast for convenient understanding

- Global attainment for your research

- Manuscript accessibility in different formats

( Pdf, E-pub, Full Text, Audio)

- Unceasing customer service

Track the below URL for one-step submission https://juniperpublishers.com/online-submission.php 